\title{
Conceptual Dissonance between Thoreau's and Wordsworth's View on Nature and Imagination
}

\author{
Mahshad Jalalpourroodsari \\ Tehran University, Tehran, Iran
}

Nature's Natural Allure vs. its Codified Nature:

In order to gain a more holistic account of the main points of focus discussed in this article, it would be illuminating to expound a bit further on the leading terms presented at the beginning of this paper. In the first place, it is essential to know that the nature perceived by Wordsworth and Thoreau is not merely the human nature explored and examined during neoclassic period by philosophers and poets such as Alexander Pope. For Wordsworth and Thoreau, nature encompasses not only the human and thus inward elements but also the outside and detached aspects of the world to which humans are exposed. In fact, for them, God's presence is sensed via man and nature alike. Furthermore, the truth embedded within such nature can be best approached through having developed the faculty of imagination which endows the mind with a divine and creative power. This sublime quality of the poet's imaginative mind would best manifest itself in moments of isolation from society which empowers him with a grand longing for unity with the object of his contemplation and appreciation. Once inspired by the very nature with which he senses a detached intimacy, he would then drown himself in welcoming it in, thus exploring the depths of the beauty he is merged with.

The premier focus of the two aforementioned figures (Wordsworth and Thoreau) is their heightened attention to nature. One might assume that the Romantic spirit revolving around their description and representation of nature would mould their understanding of it. However, this is only partly true. Thoreau looks at his surrounding with a scientist's eye trying to scrutinize its mysteries and decipher its disguised meanings. His nature has layers of significance including spiritual and material ones (Buell 171) which need to be demystified and knowable to him. As a Transcendentalist, this aspect of his work can be traced back to his mentor, Emerson, who "sacralized nature as man's mystic counterpart [believing that] nature could be decoded as a spiritually coherent sign-system" (171). The 
observative texture of Thoreau's reading of nature is enriched with a labor being analogous to a physical one which fuels his intellectual and spiritual absorption of nature (Schneider 93) in order for it to be controlled and eventually be "overcome" (100). The point to be remembered here is that, such empirically and scientifically approached nature only brings him an unnatural allure which he describes as the "cheap but pleasant effect of walking over the hills" (Buell 182). On the contrary, Wordsworth doesn't have such intellectual approach to nature. To Wordsworth, nature has the aura of present and past. It inspires him to go back in time, taste the lost hours of his youth and feel nostalgic for the "coarser pleasures of [his] boyish days / and their animal movements [which are] all gone by" (Wordsworth, "Tintern Abbey" 74-75). Such feeling triggered by the natural scenery is to Wordsworth a means of gloomy pleasure that "haunts [him] like a passion ..." (79). The time gone by of which Wordsworth talks, deprives him of a true and genuine vision of nature which could have potentially led him towards reality, and brings instead the "loss of the real life and sight" (Abbott, "Decisions of an Alarmingly Personal Nature" 115). The nostalgic sensation having high frequency in Wordsworth's poetry can equally be seen in Thoreau's work in a different manner. The desired object for Thoreau is not quite the same as Wordsworth's lost and longed for vision. His is a longing for a "pristine simplicity ... intensified by nostalgia for life at Walden" (Buell 178). Thoreau wants to go back spatially and temporally to an Eden like Walden where he could peel off all unneeded layers trapping him and preventing his "spiritual growth [attained] through nature" (Corrente, Spring 3). Hence, one can see the difference between Wordsworth and Thoreau in that Wordsworth is lamenting an already diminished or gone state of mind and feeling, whereas Thoreau's progressive growth is feasible in time through an engagement with nature.

Nature to both these poets is a refuge in which they find solitude and calm. Nevertheless, their conception of solitude sought in nature is quite different. To Thoreau, the solitary feeling provided by nature in Walden is a fluid one having the undertones of a "subversive and carnival attitude" (Schneider 102) which brings the two milieus of city and its surrounding natural environment together. Thoreau retains his "social being ...but through a continuous effort and a rigorous discipline [connects it] to the phenomena and processes of the natural world" (Taylor 236). That is why the solitude he desires gains a carnivalesque tone, in that it moves between the two domains and develops a dialogic interaction between them. For Thoreau, there is no single solitary space in which he finds solace. In line with his scientific view of nature, the serenity and solitude he pursues, would not come in a meditative account of it, but in an explorative journey between two borders (Schneider 92). On the other hand, the solitude that Wordsworth finds in nature is of a different nature. It springs from a truth value embedded within nature's bosom. 
This truth is what consoles Wordsworth and is "carried into his heart by passion" (Cited in Abbott, "Decisions of an Alarmingly Personal Nature" 116) at times when he has a "solitary walk" (Wordsworth, "Tintern Abbey" 136) amongst the hills and woods. In wandering through the hills and the mountains, he becomes a "rover ...on the lonesome peaks" (53-54) and experiences a solitary moment filled with feelings of "tranquil restoration ... [and] unremembered pleasure" (32-33). Therefore, Wordsworth's solitude is endowed with the restorative power which is quite contrary to Thoreau's subversive view of it. Wordsworth's understanding of solitude which is at odds with Thoreau's volatile perception of it, is beautifully put in his account "Of vagrant dwellers in the houseless woods / or of some hermit's cave, where by his fire / the hermit sits alone" (21-23). To Wordsworth, the solitary hermit is dissolved in nature which welcomes him inside (the cave) and provides him with a unique pleasure unremembered before. Such solitary moments can bring the gift of a blessed mood; or as Wordsworth states:

Of Aspect more sublime than blessed mood In which the burden of the mystery

Of all this unintelligible world, Is lightened- That serene and blessed mood In which the affections gently lead us on. (39-44)

Therefore, Wordsworth's solitary meditation and reflection on nature unravels the mystery of an unintelligible world, while with all his attempts to decode nature and its concealed significance, Thoreau's obsessive exploration of nature would only leave him with a "dual ...[representation of it] as both knowable and unknowable" (Schneider 101). Thus, Thoreau's unfixed positioning in Walden leads him towards forming a double facetted nature. One which lends itself to a rigorous scrutiny in the form of "discovery, retrieval and respect for the realm of physical nature" (Buell 178) and another one which extinguishes any chance of its comprehension due to its multilayered essence. The former investigative approach deprives Thoreau of what Wordsworth would call the "harmony and the deep power of joy / We see into the life of things" (Wordsworth, "Tintern Abbey" 49-50) and the latter's veiled spirit annuls any integrative marriage of self and the aloof nature.

Elemental Mission of Imagination:

Another significant aspect to be noted about Thoreau and Wordsworth is their insight into the concept of imagination. Thoreau regards the image making power as being indispensable in that he sees the "capacity for vision ... [as a] key to a successful and necessarily solitary journey of inward exploration" (Schneider 103). 
This intimate understanding of self through imagination is in line with the very dual perspective he has towards the external world. As was previously mentioned, the outside nature to Thoreau is both comprehensible and incomprehensible at the same time, and in the face of such dual account, imagination would play the essential role of facilitator and mediator. It facilitates the reading of nature's true significance which is wrapped up in coded chunks of meaning (Buell 171). Therefore, Thoreau's objective digestion of nature is facilitated by the innate power of imagination. Furthermore, in Walden, imagination provides him with the ability to bridge the "material and spiritual worlds ... the earth and the sky" (Schneider 101) through the image of the pond and its symbolic implication mirrored in its "smooth and reflecting surface" (101). Here imagination brings about a more immediate connection between the self and nature which he describes as "heaven [not being] distant in time or place but ... [being present] immediately under our feet here and now" (101).

However, In Wordsworth's poetry, imagination gains a different texture or what he would name his "purer mind" (Wordsworth, "Tintern Abbey" 31). His vision is mixed with wonder and admiration at the sight of a nature inspired from outside while reverberating inside. This is the poet's purer mind or his inward eye which creates "harmony and the deep power of joy ... in the life of things" (49-50) even though such sensation might be alien to others facing the same sublime nature. To Wordsworth, imagination is the natural offspring of being in the presence of "scattered yew-trees and the crags .../ that look upon [him]" (40-41) and make his heart beat fast. It is when he is filled with inspiration and expectation that he can color the world with his imagination. This elevated state for Wordsworth is an involuntary one, in that it rushes and takes control of his vision:

My anxious visitation hurrying on

Still hurrying, hurrying onward, how my heart

Panted - among the scattered yew-trees and the crags

That looked upon me, how my bosom beat

With expectation! Sometimes strong desire

Resistless overpowered me, and the bird

Which was the captive of another's toils

Became my prey ...................... (38-45)

Therefore, it can be seen that through his vision the invading scenery becomes one with the poet when he gets filled with its strong presence and transubstantiates the natural world into his prey or object of his private imagination. However, it should be noted that to Wordsworth, such integration with nature via imagination is a slippery one that diminishes as the time goes by. The fact of its gradual extinction 
causes him pain as he becomes unable to form a clear picture of what he sees and can only receive a "recognition [which is] ...dim and faint" (60).

Quite in line with Thoreau's analytical account of nature, it can be stated that his perspective of his role as an imaginative poet-creator was entirely different from that of Wordsworth's. Thoreau never believed himself to be a common observer but a man endowed with an astute intelligence unlocking the "laboratory of creation ... [and] declaring the ...operations of nature" (Richardson 19). Hence, while for Wordsworth, the retreat to the past is a cause of grief due to the loss of his vision and imagination, Thoreau's retreat is of an utterly unequal nature:

This retreat gives him time to reflect on the past ...it affords Thoreau new views of the familiar landscape by allowing him to walk over its surface, measure it with surveying tools, and observe the new uses to which men and animals put it. Thoreau then comes full circle with his vision of nature resurrected. (Schneider 97)

Wordsworth immerses himself in his vision and the outward sight inspiring him, whereas Thoreau keeps the necessary distance from his object of study. Thoreau makes an effort to resurrect the nature thus viewed in a god-like manner. Whereas to Wordsworth the poet has no divine quality, to Thoreau the Transcendentalist, "imagining something is in a way creating something, man could create God [and nature] ... and being who was capable of creating the divine must be divine himself" (Corrente, Spring 3). Thus, Thoreau's imagination takes him so far as replacing the supreme reality engendering it all. He reactualizes nature and engages in adoring his creation through presenting compliments to it (Thoreau 179). On the other hand, Wordsworth keeps no distance from nature and gives himself no such supreme position. His existence is melted into that of nature's which demands no intellectual or godlike action in the face of the immense pleasure derived from their interplay. It is true that Wordsworth feels the presence of God in nature, nevertheless:

Of visitation from the living God

He did not feel the God, he felt his works

Thought was not; in enjoyment it expired

He neither prayed nor offered thanks or praise;

His mind was a thanksgiving to the power

That made him. It was blessedness and love. (Wordsworth, "Pedlar" 108-114)

It can be seen that to Wordsworth, the conjured up sensations are different from Thoreau's. While both Thoreau and Wordsworth look at nature as a "source of 
inspiration" (Witherell 57), their inspirations are dissimilar and diverge into unlike paths. Wordsworth is inspired to plunge in nature and thank his blessed power of imagination which brings him joy and love, whereas Thoreau's praise of nature takes him up and above any common and ordinary joy devoid of any motive to comprehend and dominate it.

Therefore, it can be stated that Wordsworth and Thoreau's account of nature and their ostensibly similar journeys therein, are in fact quite demarcated in their various understanding of its significance, beauty and intricacy. Acknowledging the unique imaginative angle through which they look at their natural surroundings, makes one have a more thorough appreciation of their poetic worlds engraved and ornamented with subtle touches which would be hidden to an inattentive observer.

\section{References and notes:}

Abbott, Ruth. "Decisions of an Alarmingly Personal Nature, or, What I Think About William Wordsworth." Arts \& Humanities in Higher Education 6, 1(Jan. 2007): 114 122.

---. "Nostalgia, Coming Home, and the End of the Poem: On Reading William Wordsworth's Ode. Intimations of Immortality from Recollections of Early Childhood." Memory Studies 3, 3 (June 2010): 204-214.

Buell, Lawrence. "Thoreau and the Natural Environment." Cambridge Companion to Henry

David Thoreau. Ed. Joel Myerson. NY: Cambridge Un. Press, 1995: 171-189.

Corrente, Linda, and Michael Spring. Henry David Thoreau's Walden. Ed. Michael Spring.

NY: Barron's Educational Series, 1984.

Richardson, Robert D. "Thoreau and Concord." Cambridge Companion to Henry David Thoreau. Ed. Joel Myerson. NY: Cambridge Un. Press, 1995: 12-24.

Ruston, Sharon. Romanticism. NY: Continuum, 2007.

Schneider, Richard J. "Walden." Cambridge Companion to Henry David Thoreau. Ed. Joel Myerson. NY: Cambridge Un. Press, 1995: 92-106.

Taylor, Bob Pepperman. "Henry Thoreau and the Natural Life." Organization and Environment 18, 2 (June 2005): 235-240.

Thoreau, Henry David. Walden or, Life in the Woods. Washington, DC: Library of Congress, 1854.

Witherell, Elizabeth Hall. "Thoreau as Poet." Cambridge Companion to Henry David Thoreau. Ed. Joel Myerson. NY: Cambridge Un. Press, 1995: 57-70.

Wordsworth, William. "Tintern Abbey." William Wordsworth: The Pedlar, Tintern Abbey, the Two-Part Prelude. Ed. Jonathan Wordsworth. Cambridge: Cambridge Un. Press, 1985: 33-41. 


\title{
Summary
}

\section{Conceptual Dissonance between Thoreau's and Wordsworth's View on Nature and Imagination}

\author{
Mahshad Jalalpourroodsari, \\ Tehran University, Tehran, Iran
}

Henry David Thoreau (1817-1862) and William Wordsworth (1770-1850) belong to two different sects. The former is a Transcendentalist or a member of American Romanticism with its unifying account of self and nature, and the latter is an English Romantic poet belonging to a group of poets called the "lake School [or] the lakers" (Ruston 90-91) who were involved in the appreciation of and dissolution in their natural surroundings. Despite the fact that these two figures have much in common, there are points and junctures where they diverge in their perspectives towards the essential grounds of their parallel philosophies. Through having a look at Thoreau's Walden and Wordsworth's Tintern Abbey, this paper would attempt to present a broad account of the major aspects in which their literary ideas and points of views approach or diverge in regards to nature and imagination.

Key Words: Nature, Imagination, Solitude, Inspiration, Meditation/Exploration. 